\title{
Kualitas Pelayanan Berpengaruh Positif terhadap Kepuasan Pelanggan Café di Kabupaten Garut
}

\author{
Siska Marlina'; Wufron Wufron² \\ ${ }^{1}$ Universitas Garut \\ siskamarlina@uniga.ac.id \\ ${ }^{2}$ Universitas Garut \\ wufron@uniga.ac.id
}

\begin{abstract}
Abstrak
Penelitian ini bertujuan untuk mengetahui bagaimana pengaruh kualitas pelayanan terhadap kepuasan pelanggan cafe di kabupaten Garut. Metode penelitian yang digunakan dalam penelitian ini adalah metode deskriptif dan metode verifikatif. jumlah sampel yang diambil dalam penelitian ini adalah sebanyak 97 responden menggunakan teknik pengambilan sampel purposive sampling, yaitu memberi peluang atau kesempatan yang sama bagi setiap anggota populasi dalam penelitian. analisis data yang digunakan adalah analisis regresi linier sederhana untuk menguji pengaruh langsung kualitas pelayanan terhadap kepuasan pelanggan. Berdasarkan hasil penelitian bahwa kualitas pelayanan berpengaruh signifikan terhadap kepuasan pelanggan Cafe di Kabupaten Garut.
\end{abstract}

Kata Kunci: Café, Kualitas Pelayanan, Kepuasan Pelanggan

\begin{abstract}
This study aims to determine how the influence of service quality on customer satisfaction cafe in Garut. The research method used in this research is descriptive method and verification method. The number of samples taken in this study were 97 respondents using a purposive sampling technique, which provides equal opportunities or opportunities for each member of the population in the study. The data analysis used is simple linear regression analysis to test the direct effect of service quality on customer satisfaction. Based on the results of the study that the quality of service has a significant effect on customer satisfaction Cafe in Garut.
\end{abstract}

Keywords: Café, Customer Satisfaction, Service Quality

\section{Pendahuluan}

Bisnis yang bersaing dengan ketat serta kemajuan akan globalisasi saat ini membuat berbagai perusahaan untuk berlomba-lomba mempertahankan dan merebut pangsa pasar. Bukan hanya perusahaan yang sudah bertaraf internasional saja tetapi usaha kecil menengahpun juga mengalami persaingan. Meningkatnya intensitas persaingan dan jumlah pesaing menuntut perusahaan untuk selalu memperhatikan kebutuhan dan keinginan pelanggan serta berusaha 
memenuhi harapan pelanggan dengan cara memberikan pelayanan yang lebih memuaskan daripada yang dilakukan oleh pesaing.

Menurut Faradisa et al. (2019) kebiasaan kumpul di cafe telah menajadi kebiasaan masyrakat Indonesia terlebih para pelajar maupun orang dewasa. Kebiasaan inilah yang membuat banyak pengusaha yang melirik bisnis cafe. Terlebih cafe yang awal mulanya memiliki fungsi sebagai kedai kopi, mengalami pergesearan fungsional, yaitu sesuai dengan perkembangan jaman, cafe telah memilih banyak konsep, diantaranya sebagai tempat menikmati hidangan atau dinner.

Banyak sekali café yang berkembang di Kabupaten Garut, yang merupakan banyak sekali cafe beberapa diantaranya di jalan terusan pembangunan. Mnjual produk jenis minuman kopi Arabica dan jenis kopi lainnya. Seperti halnya Le Cafe Akustik Garut, usaha tersebut dimulai pada tahun 2014 yang bergerak dibidang minuman jenis kopi. Setelah dilakukan sedikit wawancara dengan perusahaan pada dasarnya produk dari café menyediakan minuman berorientasi pada bahan dasar kopi, berdasarkan perkembangannya sesuai tuntutan pasar dan konsumen. Banyak café yang mulai berekplorasi pada produk-produk yang berbahan dasar jenis-jenis kopi. Produk-produk yang dibuat tetap berpegang teguh pada konsep awal yakni memperkenalkan citra rasa kota Garut dalam bentuk atau dalam kemasan produknya. Lewat ide penggabungan kopi khas Garut dengan citra rasa kopi dan lahirlah minuman kopi produksi.

Hal tersebut dijadikan peluang bagi pemilik usaha cafe untuk dapat menciptakan usaha dengan tingkat pesaing yang sedikit dan agar dapat mencapai tujuan dari usaha. Untuk mencapai tujuan tersebut tentunya tidak terlepas dari pentingnya penerapan kualitas pelayanan yang baik agar penjualan yang diperoleh semakin meningkat setiap kurun waktunya. Berikut merupakan data hasil penjualan minuman kopi salah satu café di Kabupaten Garut sebagai gambaran bagaimana data kinerja perusahaan bisnis café di garut.

Tabel 1: Hasil penjualan salah satu café tahun 2019

\begin{tabular}{cccc}
\hline Bulan & $\begin{array}{c}\text { Penjualan } \\
\text { Kopi (Pergelas) }\end{array}$ & $\begin{array}{c}\text { Target } \\
\text { Kopi (Pergelas) }\end{array}$ & $\begin{array}{c}\text { Pencapaian } \\
\text { hasil (\%) }\end{array}$ \\
\hline Januari & 187 & 250 & 75 \\
\hline Februari & 219 & 250 & 88 \\
\hline Maret & 172 & 250 & 69 \\
\hline April & 185 & 250 & 74 \\
\hline Mei & 241 & 250 & 96 \\
\hline Juni & 199 & 250 & 80 \\
\hline Juli & 242 & 250 & 97 \\
\hline Agustus & 202 & 250 & 81 \\
\hline September & 198 & 250 & 82 \\
\hline Oktober & 205 & 250 & 76 \\
\hline November & 189 & 250 & 84 \\
\hline Desember & 210 & 250 & 82 \\
\hline$\sum$ & 2449 & 3000 &
\end{tabular}

Sumber: Le Cafe Akustik Garut 2019

Jumlah penjualan minuman kopi pada tahun 2019 mengalami fluktuatif dan tidak mencapai target yang telah ditetapkan perusahaan, target yang ditetapkan perusahaan sebanyak 250 minuman kopi. dengan pencapaian target sebesar 84\%. Pencapaian target penjualan tahunan tidak tercapai sesuai perencanaan pengelola yaitu sebanyak 3000 minuman kopi, hanya tercapai 
82\% dari target yang telah ditetapkan perusahaan dan hanya dapat menjual 2449 minuman kopi pertahun. Penjualan yang fluktuatif dan tidak tercapainya target penjualan mengindikasikan bahwa minat berkunjung kembali masyarakat untuk membeli minuman kopi di perusahaan ini masih kurang, hal ini dapat diakibatkan oleh kualitas pelayanan yang kurang memenuhi harapan konsumen sehingga konsumen tidak puas.

Berdasarkan hasil wawancara peneliti terhadap pemilik café, penurunan penjualan tersebut, diindikasikan karena pelayan yang ada tidak sesuai dengan yang diharapkan oleh pelanggan yang berkunjung, hal ini berdampak pada adanya pelanggan yang mengeluh akibat dari pelayanannya yang kurang memuaskan tersebut, seperti pelanggan yang tidak dilayani dengan cepat, waktu menunggu pelanggan yang sangat lama ketika penjual mencoba mengambil barang yang sesuai keinginan pelanggan, kurangnya ketersediaan stok barang yang diinginkan pelanggan serta hal lain sebagai nya.

Kepuasan pelanggan merupakan perasaan puas yang dimiliki konsumen setelah membeli produk atau jasa. Menurut (Noeraini, 2016) bahwa kepuasan adalah perasaan senang atau kecewa seseorang yang timbul karena membandingkan kinerja yang dipersepsikan produk (atau hasil) terhadap ekpetasi mereka. Jika kinerja gagal memenuhi ekpetasi, pelanggan akan tidak puas. Konsumen merasa pelayanan yang diberikan beberapa café tidak sesuai dengan harapan konsumen dan harga menu yang disediakan kurang terjangkau sehingga menyebabkan konsumen merasa tidak puas dengan pelayanan dan harga yang diberikan.

Menurut Noeraini (2016) bahwa kepuasan pelanggan merupakan perasaan senang atau kecewa seseorang yang timbul karena membandingkan kinerja yang dipersepsikan produk (atau hasil) terhadap ekpetasi mereka. Jika kinerja gagal memenuhi ekpetasi, pelanggan akan tidak puas. Apabila seseorang sudah memiliki minat atau niat berkunjung untuk membeli suatu produk, penilaian itu dapat dilihat dari kualitas pelayanan, menurut Noeraini (2016) kualitas pelayanan merupakan tingkat keunggulan yang diharapkan dan pnegendalian atas tingkat keunggulan tersebut untuk memenuhi keinginan pelanggan terhadap suatu perusahaan. apabila kualitas pelayanan baik disuatu perusahaan maka akan terciptanya kepuasan pelanggan terhadap perusahaan tersebut. Selain kualitas pelayanan yang memberikan pelayanan baik terhadap konsumen.

Kualitas pelayanan yang baik akan menentukan sikap konsumen dalam menilai, memutuskan sekaligus memberikan kesan terhadap pelayanan yang diberikan, karena seringkali konsumen yang merasa puas akan cenderung lebih loyal terhadap perusahaan itu. Yang terjadi saat ini yaitu pelanggan yang mengkonsumsi dan menikmati pelayanan yang diberikan oleh perusahaan, sehingga pelangganlah yang bisa menilai kualitas pelayanan. Hal ini berarti kualitas pelayanan yang baik bukan dilihat dari sudut pandang perusahaan tetapi dilihat dari sudut pandang pelanggan Wahab (2017)

Perusahaan perlu untuk mengevaluasi dan meningkatkan kualitas pelayanan agar kepuasan pelanggan dapat dirasakan oleh setiap pelanggan yang mengunjungi perusahaan tersebut baik itu pelanggan tetap maupun pelanggan yang baru. Dengan memberikan pelayanan yang maksimal tidak menutup kemungkinan konsumen merasa puas, kepuasan konsumen merupakan perasaan puas yang didapat setelah membeli produk/jasa. Menurut Efendi \& Imamah (2017) kepuasan merupakan akumulasi dari penilaian konsumen atau akumulasi penilaian konsumen dalam menggunakan produk dan jasa, setiap pengalaman baru atau transaksi yang akan memberikan pengaruh terhadap kepuasan. 
Kualitas pelayanan yang diberikan kepada konsumen tidak sesuai dengan harapan tentunya akan merugikan bagi pihak pelaku usaha. Jika ingin memuaskan pelanggan perlu adanya perbaikanperbaikan seperti dengan ada pelayanan yang baik dan cepat agar pelanggan tidak merasa jenuh dalam menunggu pesanan yang dipesan serta memperhatikan apa saja yang menjadi faktor keputusan pelanggan dalam berkunjung kembali.

\section{Tinjauan Pustaka}

Kualitas pelayan merupakan tingkat keunggulan yang diharapakan dan pengendalian atas tingkat keunggulan tersebut untuk memenuhi keinginan pelanggan. Apabila jasa atau pelayanan yang diterima atau dirasakan (perceived service) sesuai dengan yang diharapkan atau melampaui harapan pelanggan, maka kualiatas jasa atau pelayanan dipersepsikan baik, ideal dan memuaskan. Sebaliknya jika jasa atau pelayanan yang diterima lebih rendah dari pada yang diharapkan, maka kualiatas pelayanan dipersepsikan buruk (Susepti et al., 2017).

Setelah melalui berbagai tahapan yang terjadi dalam proses persepsi kemudian langsung dilanjutkan pada tahapan keterlibatan konsumen. Dengan terciptanya kualitas pelayan yang baik di masyarakat maka konsumen akan semakin percaya terhadap suatu perusahaan. Kualitas pelayanan harus dimulai dari kebutuhan pelanggan dan berakhir pada persepsi pelanggan, persepsi pelanggan tentang kualitas pelayanan ke pelanggan merupakan salah satu penentu keberhasilan pemasaran. Apabila pelayanan yang diterima atau dirasakan sesuai dengan yang diharapkan maka kualitas pelayanan akan dipersepsikan baik dan memuaskan (Tjiptono. Fandy, 2017).

Kualitas pelayanan merupakan tingkat keunggulan yang diharapkan dan pnegendalian atas tingkat keunggulan tersebut untuk memenuhi keinginan pelanggan Noeraini (2016). Krisdayanto et al. (2018) mengemukakan bahwa kualitas pelayanan merupakan seberapa jauh perbedaan antara kenyataan dan harapan pelanggan atas kepuasan pelanggan yang merka terima atau peroleh. Adanya kualitas pelayanan yang baik dan dirasakan dengan baik dimata konsumen akan menimbulkan loyalitas dari konsumen untuk perusahaan. Dari beberapa pengertian kualitas pelayanan maka dapat disimpulkan bahwa kualitas pelayanan yaitu kesesuaian yang diharapakan oleh pelanggan dengan penyedia jasa sesuai dengan tingkat pelayanan yang diberikan dalam memenuhi harapan dan keinginan pelanggan, dimana pelanggan dapat merasakan dan meyakini terhadap kualitas pelayanan tersebut sehingga dapat membangun nama baik perusahaan dan diingat konsumen.

Dimensi kualitas pelayanan (Tjiptono. Fandy, 2017) yaitu:

1. Reliabilitas (Reliability) adalah konsistensi dari penampilan dan kehandalan pelayanan yaitu kemampuan perusahaan dalam memberikan pelayanan yang dijanjikan dengan segera mungkin, akurat dan juga memuaskan.

2. Daya Tanggap (Responsiveness) yaitu kesigapan serta kecepatan penyedia jasa dalam menyelesaikan masalah dan memberikan pelayanan dengan tanggap.

3. Jaminan (Assurance) yaitu kemampuan dan keterampilan dalam melakukan pelayanan, keramahan petugas, dan kepercayaan.

4. Empati (Empathy) yaitu kemudahan dalam melakukan hubungan kombinasi yang baik, perhatian secara pribadi dan memahami kebutuhan para pelanggan

5. Bukti Fisik (Tangible) yaitu fasilitas fisik yang ditawarkan kepada konsumen yang meliputi fisik, perlengkapan, pegawai dan sarana komunikasi. 
Payne (2013) mengemukakan faktor-faktor yang mempengaruhi kualitas pelayanan yaitu rasa menyenangkan atau tidak menyenangkan yang diterima oleh konsumen yaitu sebagai berikut:

1. Segala kegiatan yang dibutuhkan untuk menerima, memperoses, mentransfer dan memberikan jasa kepada pihak lain dan untuk memberikan pelayanan pada setiap kegiatan .

2. Ketepatan dan cara penyampaian jasa kepada pelanggan sesuai dengan harapan mereka.

3. Serangkaian kegiatan yang meliputi semua bidang bisnis yang terpadu untuk menyampaikan produk-produk dan jasa tersebut sedemikian rupa sehingga digambarkan dapat memberikan kepuasan kepada pihak lain dan memcapai target dari tujuan perusahaan.

4. Seluruh pesanan yang ada dan seluruh hubungan dengan pelanggan.

5. Penyampaian jasa tepat waktu dan akurat dengan segala tindak lanjut serta keterangan yang valid.

Kualitas pelayanan merupakan salah satu keunggulan yang dapat mendorong konsumen merasakan kepuasan. Kepuasan merupakan suatu sikap yang diputuskan berdasarkan pengalaman yang didapatkan. Pengalaman yang diterima pelanggan salah satunya adalah pelayanan yang diterima. Apabila suatu usaha menerapkan prinsip kualtias pelayanan yang baik dan konsisten maka hal tersebut dapat menarik minat serta keinginan pelanggan untuk berbelanja pada tempat usaha tersebut. Hal itu disebabkan karena adanya perasaan nyaman dan percaya pada apa yang telah dikatan oleh pelanggan akibat dari kualitas pelayanan yang baik (Lovelock, Christopher dan Wirtz, 2016). Dalam penelitian Suminar (2017) yang menyatakan bahwa kualitas pelayanan berpengaruh secara simultan terhadap kepuasan pelanggan cafe shop Sidoarjo.

\section{$3 \quad$ Metode Penelitian}

Metode yang digunakan pada penelitian ini adalah penelitian deskriptif dan verifikatif. Deskritif digunakan untuk menggambarkan dan mejelaskan fakta-fakta serta hubungan antar fenomena yang diselidiki. Verifikatif bertujuan mengetahui hubungan sebab akibat antar variabel melalui pengujian hipotesis (Sugiyono, 2013). Metode penelitian yang digunakan untuk menggambarkan bagaimana pengaruh kualitas pelayanan terhadap kepuasan pelanggan. Menguji kebenaran hipotesis dalam penelitian, variabel yang akan diuji yaitu kualitas pelayanan dan kepuasan pelanggan. Jumlah sampel yang diambil dalam penelitian ini adalah sebanyak 97 responden menggunakan teknik pengambilan sampel purposive sampling. Alat instrumen penelitian menggunakan kuesioner penelitian. Unit analisisnya adalah individu dalam masyarakat pelanggan dari beberapa café di kabupaten garut. Alat analisis yang digunakan adalah regresi linier sederhana.

\section{Hasil Penelitian dan Pembahasan}

Berdasarkan jenis kelamin responden yang pernah berkunjung ke café di Kabupaten Garut yaitu laki-laki memiliki persentase yang paling tinggi. Hal tersebut dikarenakan cafe merupakan tempat yang paling pas untuk laki-laki berkumpul dengan teman-temannya dan juga bisa menguntungkan bagi cafe tersebut karena apabila laki-laki merasa nyaman dengan cafe tersebut maka akan melakukan kunjungan kembali sehingga dapat menguntungkan bagi pihak cafe.

Tanggapan responden mengenai Kualitas pelayanan Cafe di Kabupaten Garut memperoleh memiliki kategori baik. Hal tersebut menunjukkan bahwa Kualitas pelayanan Cafe di Kabupaten 
Garut sudah baik dan berjalan sesuai dengan tingkat keunggulan yang diharapkan untuk memenuhi kebutuhan pelanggan. Karyawan cafe di Kabuoaten Garut tidak mengalami kesulitan dalam melayani konsumen sehingga karyawan dapat memenuhi keinginan konsumen sesuai dengan harapannya. Karyawan Cafe harus mempertahankan ketangkasan dalam melayani konsumen. Maka dari itu setiap Café di Garut harus mempertahankan kesigapan dan kecepatan dalam melayani konsumen agar konsumen tidak merasa jenuh dan bosan saat memesan hidangan yang ditawarkan.

Tanggapan responden mengenai Kepuasan pelanggan Cafe di Kabupaten Garut dalam kategori baik. Hal tersebut menunjukkan bahwa Kepuasan pelanggan Cafe di Kabupaten Garut sudah meningkatkan kepuasan pada konsumen sehingga meningkatkan keuntungan bagi perusahaan dan mendapatkan pangsa pasar yang jauh lebih besar. Pesanan yang disuguhkan berbagai Café di Garut sudah sesuai dengan yang apa yang diharapkan oleh konsumen. Konsumen merasa cukup puas dengan menu yang ditawarkan berbagai Café di Garut sehingga perusahaan perlu meningkatkan fasilitas agar kebutuhan konsumen akan tercapai secara maksimal.

Berikut merupakan hasil pengujian pengaruh Kualitas pelayanan Terhadap Kepuasan pelanggan Cafe di Kabupaten Garut dengan menggunakan alat bantu IBM SPSS 22 :

Tabel 2: Coefficients ${ }^{a}$ pengaruh kualitas pelayanan terhadap kepuasan pelanggan

\begin{tabular}{|c|c|c|c|c|c|c|}
\hline \multirow[t]{2}{*}{ Model } & & \multicolumn{2}{|c|}{ Unstandardized Coefficients } & \multirow{2}{*}{\begin{tabular}{|c|}
$\begin{array}{c}\text { Standardized } \\
\text { Coefficients }\end{array}$ \\
Beta
\end{tabular}} & \multirow[t]{2}{*}{$\mathbf{t}$} & \multirow[t]{2}{*}{ Sig. } \\
\hline & & B & Std. Error & & & \\
\hline & (Constant) & 29.302 & 4.410 & & 6.645 & .000 \\
\hline 1 & $\begin{array}{l}\text { Kualitas } \\
\text { pelayanan }\end{array}$ & .262 & .114 & .231 & 2.298 & .024 \\
\hline
\end{tabular}

a. Dependent Variable: Kepuasan pelanggan

Sumber: Output SPSS

Berdasarkan tabel 2 diperoleh nilai coefficients pengaruh kualitas pelayanan terhadap kepuasan pelanggan sebesar +0.262 artinya kualitas pelayanan memiliki pengaruh positif terhadap kepuasan pelanggan bahwa semakin tinggi nilai kualitas pelayanan maka kepuasan pelanggan akan meningkat. Artinya jika kualitas pelayanan sudah sesuai dengan keinginan pelanggan maka akan tercipta kepuasan pelanggan. Dengan signifikansi 0,024 kurang dari 0,05 maka $\mathrm{H}_{02}$ ditolak artinya kualitas pelayanan berpengaruh signifikan terhadap kepuasan pelanggan. Berarti terdapat pengaruh kualitas pelayanan terhadap kepuasan pelanggan Cafe di Kabupaten Garut. Fasilitas fisik yang ditawarkan kepada konsumen yang meliputi fisik, perlengkapan, pegawai dan sarana komunikasi akan berpengaruh terhadap harapan konsumen terhadap suatu barang atau jasa telah dibentuk sebelum konsumen membeli barang atau jasa tersebut. Sejalan dengan penelitian yang dilakukan oleh Rahmidani et al. (2020) bahwa kualitas pelayanan berpengaruh signifikan terhadap kepuasan pelanggan.

\section{$5 \quad$ Simpulan dan Saran}

Kualitas pelayanan Cafe di Kabupaten Garut mendapatkan tanggapan yang baik dari responden secara keseluruhan. Kualitas pelayanan menggambarkan karyawan tidak mengalami kesulitan dalam melayani konsumen. Hal ini menggambarkan bahwa berbagai Café di Kabupaten Garut memang tidak mengalami kesulitan dalam melayanai konsumen, terlihat dari tanggapan responden dengan kriteria baik. Kepuasan pelanggan Cafe di Kabupaten Garut menunjukkan 
adanya penilaian baik dari responden secara keseluruhan. Kepuasan pelanggan menggambarkan perusahan Café di Garut memberikan kenyamanan yang unik dibandingkan dengan Cafe di kota lain. Hal ini menggambarkan bahwa Café di Garut memang memberikan kenyamanan dibandingkan dengan Cafe di kota lain. Kualitas pelayanan memiliki pengaruh positif terhadap kepuasan pelanggan. Kualitas pelayanan berpengaruh signifikan terhadap Kepuasan pelanggan Cafe di Kabupaten Garut. Sehingga jika kualitas pelayanan meningkat maka kepuasan pelanggan akan ikut meningkat.

Karyawan Café di Kabupaten Garut kurang tangkas dalam melayani konsumen. Oleh karena itu. Pihak perusahaan sebaiknya melakukan pelatihan terlebih dahulu kepada karyawan yang akan melakukan pekerjaanya agar karyawan tersebut tangkas dalam memberikan pelayanan kepada konsumen. Konsumen belum merasa puas dengan menu yang ditawarkan perusahaan Café di Kabupaten Garut. Sebaiknya perusahaan memberikan banyak lagi varian menu untuk ditawarkan kepada konsumen.

\section{Daftar Pustaka}

Dewi, R. S., Widodo, P., \& Budiarti, L. N. (2016). Pengaruh Unsur Alam terhadap Minat Berkunjung Kembali di Mal. Journal of Visual Art.

Faradisa, I., Budi, L., \& Minarsih, M. M. (2019). Analisis Pengaruh Variasi Produk, Fasilitas, dan Kualitas Pelayanan terhadap Minat Beli Ulang Konsumen pada Indonesian Coffee Shop Semarang (ICOS CAFE). Journal of Management, 02(02), 1-13.

Krisdayanti., Haryono, A. T., PT, E. G., Analisis, H., Pelayanan, A. K., Fasilitas, L., \& Putra, net B. (2018). Analisis pengaruh harga, kualitas pelayanan, fasilitas, dan lokasi terhadap kepuasan konsumen di i cafe lina putra net bandungan. Journal of Management, 4(4).

Lin, C.H. 2012. Effects of Cuisine Experience, Psychological Well-Being, And SelfHealth Perception on the Revisit Intention of Hot Springs Tourists. Journal of Hospitality \& Tourism Research, p. 1-22.

Noeraini, I. A. (2016). Pengaruh Tingkat Kepercayaan, Kualitas Pelayanan, dan Harga Terhadap Kepuasan Pelanggan JNE Surabaya. Ilmu Dan Riset Manajemen, ISSN: 2461-0593, 5(5), 1-17.

Priansa, D. J. (2017). Dalam Persaingan Bisnis Kontemporer. In Perilaku Konsumen. CV. Alfabeta.

Sastri, Y. Y., Ramadhin, M. D., \& Triastity, R. (2019). Pengaruh Experiential Marketing terhadap Minat Berkunjung Ulang dengan Kepuasan Pengunjung Sebagai Variabel Mediasi (Survei pada Pengunjung Taman Pelangi Jurug Surakarta) Yeni. Jurnal Ekonomi Dan Kewirausahaan, 19(1), 92-105.

Tjiptono. Fandy. (2011). Pemasaran Jasa. Uin Malang:Bayumedia 